\title{
Biomass and respiratory ETS activity of microplankton in the Barents Sea
}

\author{
ROSA MARTINEZ
}

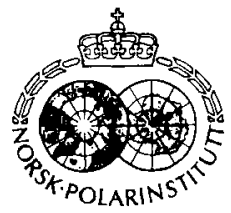

\begin{abstract}
Martinez, R. 1991: Biomass and respiratory ETS activity of microplankton in the Barents Sea. Pp. 193200 in Sakshaug. E., Hopkins, C. C. E. \& Øritsland, N. A. (cds.): Proccedings of the Pro Mare Symposium on Polar Marine Ecology, Trondheim, 12-16 May 1990. Polar Research 10(1).

The activity of the respiratory clectron transport systcm (ETS) of microplankton was measured in the Central Barents Sea during summer 1988. In vitro ETS activity increased with assay temperature between 0 and $12^{\circ} \mathrm{C}$, as reported for other enzyme systems in plankton. The higher in situ activities were observed near the surface (upper 10-25 m) and werc associated with chlorophyll a maxima. Respiratory activity in the upper $60 \mathrm{~m}$ accounted for $40-60 \%$ of the total column respiration. The activities $(0-100 \mathrm{~m})$ were lower than oxygen consumption rates reported in the Canadian Arctic, mainly due to lower phytoplankton biomass. They were higher than ETS activity measured in the Weddell Sea (Antarctic Ocean). A high detrital versus total microplankton mass accounted for the low activity related to particulate organic carbon (POC). In general, the levels of respiratory ETS activity were in the range reported for temperate oligotrophic oceanic regions.
\end{abstract}

Rosa Martinez, Departamento de Ciencias y Técnicas del Agua, Universidad de Cantabria, E-39005 Santander, Spain (revised June 1991).

\section{Introduction}

Direct measurements of respiration are scarce compared with the wealth of data on primary production. In contrast to photosyrithesis, respiration is a process common to all organisms, and occurs throughout the whole water column. The microplankton fraction has been shown to be the most metabolically active in different ocean regions (Williams 1981; Packard \& Williams 1981; Mann 1982; Williams 1984; Packard 1985a).

Oxygen consumption by respiration is mostly due to oxidative phosphorylation, driven by the respiratory electron transport system (ETS), and the measurement of the activity of this system yields the maximum potential respiration (Packard 1971, 1985a). Data for real-time instantaneous rates of respiratory activity in ocean regions can be obtained through measurement of ETS activity. This method facilitates the measurement of large numbers of samples and the determination of very low respiration rates, while avoiding the need for incubations (Packard 1985b).

Both growth and metabolic rates in plankton are limited by low temperatures (Packard et al. 1975; Neori \& Holm-Hansen 1982). Adaptation of organisms to low temperatures can be achieved through biochemical mechanisms. Somero (1969) and Hochachka \& Somero $(1971,1973)$ found a decrease in the Ea at near-zero temperatures in cold-adapted marine organisms. Chabot (1979) postulated an increase in mitochondrial oxidation under lower growth temperature, involving enzyme increase. There is no conclusive evidence of these mechanisms in microplankton (Packard et al. 1975; Li et al. 1984; Tilzer et al. 1986), and there are no published data on ETS-temperature relationships in Arctic microplankton, that could contribute to clarify this question.

The Central Barents Sea experiences during the summer oligotrophic conditions, i.e. low chlorophyll $a$ concentrations and nutrient recycling (Rey \& Loeng 1985; Wassmann 1989; Wassmann et al. 1991). Therefore, low biomasses and metabolic rates are to be expected. This study was undertaken during the R/V G.O. SARS cruise to the Central Barents Sea in July 1988. Its main objective was to provide data on respiratory ETS activity in Arctic microplankton that can be compared with ETS activity and respiration rates reported from polar and other latitudes, and with primary production and other metabolic rates.

\section{Study area}

Three stations were chosen which represent three zones in the area: Station $1\left(73.5^{\circ} \mathrm{N}, 19^{\circ} \mathrm{E}\right)$, situ- 
ated in Atlantic Water, close to the southern edge of the Polar Front, with temperatures ranging from $-1^{\circ} \mathrm{C}$ to $7^{\circ} \mathrm{C}$ and salinities from 34.5 to 35 ; Station $2\left(76.7^{\circ} \mathrm{N}, 32.5^{\circ} \mathrm{E}\right)$, located at the Polar Front, in Arctic Water, with temperatures from $-2^{\circ} \mathrm{C}$ to $1.6^{\circ} \mathrm{C}$ and salinity from 32.5 to 35 ; Station $3\left(72.3^{\circ} \mathrm{N} .30 .5^{\circ} \mathrm{E}\right)$, well south of the Polar Front. in Atlantic Water, with coastal water influence (temperature $4^{\circ} \mathrm{C}$ to $8.2^{\circ} \mathrm{C}$, salinity 34.5 to 34.8 ).

\section{Material and methods}

Microplankton samples were taken at three stations with Niskin bottles at 12 to 16 depths, from surface to about $300 \mathrm{~m}$. The water samples were screened through a $240 \mu \mathrm{m}$ net to eliminate larger zooplankters. Filtration was done on Whatman $\mathrm{GF} / \mathrm{F}$ glass fiber filters. The filters with cells were frozen in liquid nitrogen until assaying. 5 to 10liter samples were filtered for ETS assays, and $290 \mathrm{ml}$ for particulate organic carbon (POC) and nitrogen (PON).

Chlorophyll $a$ was measured on board with a Turner Designs fluorometer using acetone as extractant. Nitrate and ammonium were measured on board with a Technicon Autoanalyser, and particulate organic carbon and nitrogen were measured with a Carlo Erba CHNelemental analyser.

The respiratory ETS activity of the samples was analyzed with the Packard (1971) and Kenner \& Ahmed (1975) enzyme assay. A time and temperature kinetics study was performed on two occasions prior to assaying. For this, a large water sample (601) was taken from the chlorophyll maximum layer, thoroughly mixed and fractioned in 6 aliquots of 101 each, that were subsequently filtered and frozen in the same way as the samples. Assays were run in duplicate for each aliquot, at 6 different temperatures: $1.5,7,8,10$ and $12^{\circ} \mathrm{C}$. Several incubation times were used for each assay: $5,10,15,20$ and $25 \mathrm{~min}$. This was done to calculate the enzyme activation energy that should be used when converting activities from a single incubation temperature at which the assays were run to in situ activity, according to the equation

$\operatorname{ETS}($ in situ $)=\operatorname{ETS}($ assay $)$

$$
\times \exp \left[E_{\mathrm{ad}}\left(1 / \mathrm{T}_{\mathrm{ass}}-1 / \mathrm{T}_{\mathrm{is}}\right) / R\right]
$$

where $E_{a}$ is the activation energy of the enzyme reaction (in $\mathrm{Kcal} \mathrm{mole}^{-1}$ ), $T_{1}$ is the in situ tem- perature, $T_{\text {ass }}$ is the assay temperature (both in degrees $K$ ) and $R$ is the gas constant.

Depth-integrated biomass and ETS activity were calculated by integration of single depth values according to the equation:

$I N T(X)=\sum\left[\left(X_{\mathrm{i}}+X_{\mathrm{i}+1}\right) / 2\right] *\left(Z_{\mathrm{i}+1}-Z_{\mathrm{i}}\right)$

where $X_{i}=$ value of the variable at the depth $Z_{i}$.

\section{Results}

\section{Enzyme kinetics}

Respiratory ETS activity increased from 0 to $12^{\circ} \mathrm{C}$ in the two experiments. The mean activation energy for this temperature range, calculated from an Arrhenius plot of the results, was $11.5 \pm 0.6 \mathrm{Kcal}^{\mathrm{mole}}{ }^{-1}$, and this was the value used to calculate in situ respiratory rates of all the samples that were routinely assayed at $10^{\circ} \mathrm{C} . \mathrm{Q}_{10}$ for the 0 to $10^{\circ} \mathrm{C}$ range was 1.6 .

The reaction was linear with time for the first $15 \mathrm{~min}$. of incubation at all incubation temperatures. Consequently, the time used for all the sample incubations was $15 \mathrm{~min}$.

\section{Biomass and activity}

Table 1 summarises the results of biomass and activity variables at the three stations. Fig. 1 represents the vertical distribution of the biomass variables. The $0-60 \mathrm{~m}$ zone was considered as the euphotic zone according to the chlorophyll $a$ distribution. Nitrate and ammonium profiles at Stations 1 and 2 are shown in Fig. 2 (nitrate and ammonium data were unavailable at Station 3).

A strong nitracline developed at $20-60 \mathrm{~m}$ depth, where nitrate concentrations ranged from zero to 10 mmole $\mathrm{m}^{-3}$. Nitrate was exhausted at the surface of Atlantic as well as Arctic waters. Chlorophyll concentrations at Stations 1 and 3 were low, corresponding to the post-bloom stage. The peak of Station 1 was situated at the nitracline, about $25 \mathrm{~m}$, and amounted to $0.3 \mathrm{mg} \mathrm{m}^{-3}$. Station 2 showed the features of a bloom situation (Rey et al. 1987) with the chlorophyll peak located at $12 \mathrm{~m}$ depth, just above the nitracline, although it represented only $3 \mathrm{mg} \mathrm{m}^{-3}$. Mean chlorophyll $a$ concentration was an order of magnitude higher at Station $2\left(0.58 \mathrm{mg} \mathrm{m}^{-3}\right)$ than Station 1 (0.059 $\mathrm{mg} \mathrm{m}^{-3}$ ). 
Table 1 . Mean values of biochemical variables for the three stations.

\begin{tabular}{|c|c|c|c|c|c|c|}
\hline Variable & Station & Mean & S.D. & Min. & Max. & $n$ \\
\hline \multirow[t]{4}{*}{$\mathrm{POC}\left(\mathrm{mg} \mathrm{m}^{-3}\right)$} & 1 & 113 & 69 & 49 & 235 & 16 \\
\hline & 2 & 142 & 127 & 54 & 499 & 15 \\
\hline & 3 & 233 & 106 & 70 & 411 & 11 \\
\hline & All & 155 & 111 & 49 & 499 & 42 \\
\hline \multirow[t]{4}{*}{ PON (mg m ${ }^{-3}$ ) } & 1 & 13.4 & 10.8 & 4.1 & 39.7 & 16 \\
\hline & 2 & 16.7 & 16.4 & 5.5 & 64.2 & 15 \\
\hline & 3 & 23.4 & 10.9 & 6.1 & 40.0 & 11 \\
\hline & All & 17.2 & 13.4 & 4.1 & 64.2 & 42 \\
\hline \multirow[t]{4}{*}{ Chla $\left(\mathrm{mg} \mathrm{m}^{-3}\right)$} & 1 & 0.06 & 0.06 & 0.01 & 0.20 & 16 \\
\hline & 2 & 0.60 & 0.94 & 0.02 & 3.26 & 15 \\
\hline & 3 & 0.20 & 0.22 & 0.01 & 0.61 & 11 \\
\hline & All & 0.29 & 0.60 & 0.01 & 3.26 & 42 \\
\hline ETS & 1 & 0.25 & 0.25 & 0.05 & 0.87 & 16 \\
\hline \multirow[t]{3}{*}{$\left(\mathrm{ml} \mathrm{O} \mathrm{O}^{-3} \mathrm{~h}^{-1}\right)$} & 2 & 0.47 & 0.78 & 0.06 & 3.10 & 15 \\
\hline & 3 & 0.51 & 0.37 & 0.17 & 1.23 & 11 \\
\hline & All & 0.40 & 0.5 & 0.05 & 3.10 & 42 \\
\hline \multirow{4}{*}{$\begin{array}{l}\mathrm{POC} / \mathrm{Chl} a(\mathrm{w} / \mathrm{w}) \\
(0-100 \mathrm{~m})\end{array}$} & 1 & 2536 & 2103 & 1179 & 6780 & 8 \\
\hline & 2 & 342 & 222 & 105 & 814 & 9 \\
\hline & 3 & 1404 & 1146 & 365 & 3406 & 6 \\
\hline & All & 1424 & 1097 & 105 & 6780 & 25 \\
\hline \multirow{4}{*}{$\begin{array}{l}\text { ETS/Chla } \\
\left(\mathrm{mlO}_{2} \mathrm{mg}^{-1} \mathrm{~h}^{-1}\right) \\
(0-100 \mathrm{~m})\end{array}$} & 1 & 5.11 & 4.01 & 0.85 & 14.50 & 8 \\
\hline & 2 & 0.87 & 0.55 & 0.23 & 2.00 & 9 \\
\hline & 3 & 2.39 & 0.52 & 1.60 & 3.12 & 6 \\
\hline & All & 2.69 & 2.50 & 0.23 & 14.50 & 25 \\
\hline \multirow[t]{4}{*}{$\mathrm{C} / \mathrm{N}$ (at/at) } & 1 & 12.1 & 3.7 & 7.4 & 19.6 & 16 \\
\hline & 2 & 11.4 & 2.0 & 7.7 & 15.8 & 15 \\
\hline & 3 & 12.7 & 1.4 & 10.4 & 15.6 & 11 \\
\hline & All & 12.0 & 2.7 & 7.4 & 19.6 & 42 \\
\hline \multirow[t]{4}{*}{ C-sp. ETS $\left(\mathrm{d}^{-1}\right)$} & 1 & 0.027 & 0.013 & 0.008 & 0.048 & 16 \\
\hline & 2 & 0.033 & 0.020 & 0.011 & 0.068 & 15 \\
\hline & 3 & 0.030 & 0.017 & 0.010 & 0.056 & 11 \\
\hline & All & 0.030 & 0.017 & 0.008 & 0.068 & 42 \\
\hline
\end{tabular}

POC and PON distributions (Fig. 1) varied among the 'stations. At Station 1 they showed peaks in the upper $50 \mathrm{~m}$, just above the ammonium peaks, with concentrations of 236 and $40 \mathrm{mg} \mathrm{m}^{-3}$, respectively. Increases in POC and PON did not show any correspondence with increases in chlorophyll, which implies that they were probably related mainly to microheterotrophs and/or detrital matter. Station 2 exhibited the highest single-depth POC and PON maxima, 499 and $64 \mathrm{mg} \mathrm{m}^{-3}$, corresponding to the chlorophyll maximum. Maximum POC and PON concentrations at Station 3 were 410 and $19 \mathrm{mg} \mathrm{m}^{-3}$, respectively, at $50 \mathrm{~m}$ depth, clearly below the chlorophyll maximum, which was located at $20 \mathrm{~m}$.

Fig. 3 shows in situ ETS activity and carbonspecific ETS activity. The activity was highest in the chlorophyll maximum at the three stations, suggesting that most of the microplankton metabolic activity takes place in the upper $40 \mathrm{~m}$ and is mainly due to phytoplankton (and possibly also to micrograzers). Maximum values were $0.9,1.3$ and $3.1 \mathrm{ml} \mathrm{O}_{2} \mathrm{~m}^{-3} \mathrm{~h}^{-1}$, at Stations 1,2 and 3 , respectively. Minimum activities occurred at intermediate depths (about $100 \mathrm{~m}$ ) and a slight increase was observed at Station 1 near the bottom, probably due to an increase of bacterial biomass.

At Station 1, ETS activity showed good correlations with $\mathrm{POC}, \mathrm{PON}$ and chlorophyll $\left(\mathrm{r}^{2}>0.6\right)$. The correlations were highest at Station 2: $r^{2}=0.7$ for POC; $r^{2}=0.8$ for PON and $r^{2}=0.9$ for chlorophyll. At Station 3 , the activity was only correlated with chlorophyll $\left(r^{2}=0.9\right)$ and not with POC or PON. (All correlations had $\mathrm{P}<0.001)$. POC and PON were strongly 


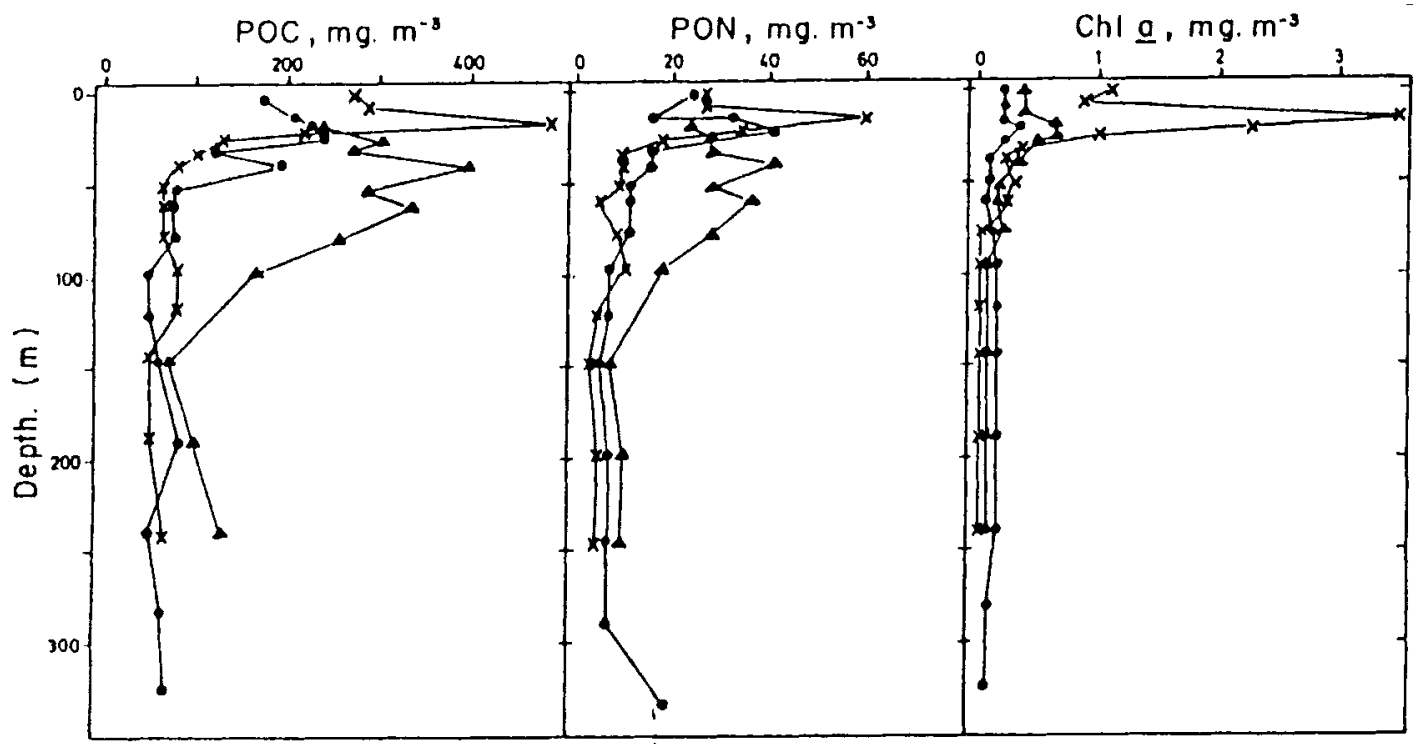

Fig. 1. Depth profiles of the hiomass variables. POC. PON and chlorophyil a Station $1: x-x=$ Station 2: $\boldsymbol{\Delta}-\boldsymbol{\Delta}=$ Station 3 .

correlated at this station $\left(r^{2}=0.97\right)$ and chlorophyll-independent, which further indicates that an important proportion of the particulate organic matter was detrital or microheterotrophic.

$\mathrm{C} / \mathrm{N}$ (at/at) ratios had a mean value of 12 . The ratios were highest at Station 3, suggesting the existence of more detrital material. Significant differences $(P<0.05)$ were found for the $C / N$ ratio between Station 3 (all values) and the other two stations.

$\mathrm{POC} / \mathrm{Chl}$ ratios were high due to the predominance of heterotrophic organisms and detritus during summer, as compared with a POC/ Chl ratio of 59 for phytoplankton during the spring bloom (Rey unpubl. obser.). In the chlorophyll maximum at Station 2, the ratio had a mini-

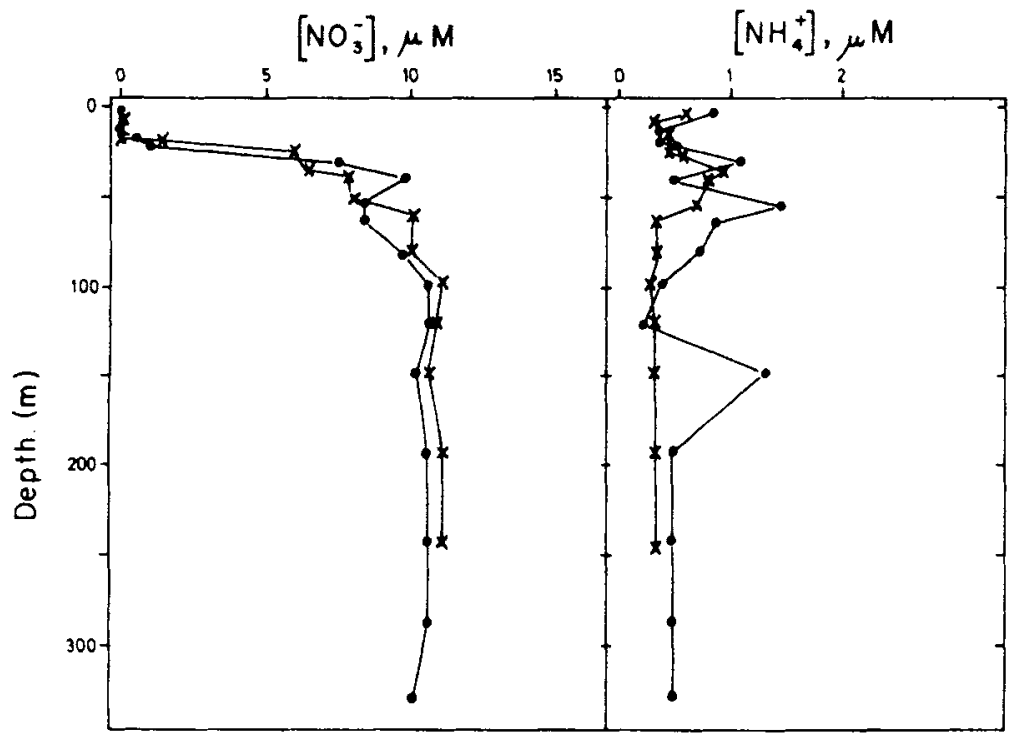

Fig. 2. Depth profiles of nitrate and ammonium at Stations 1 and 2: $-=$ Station 1: $x-x=$ Station 
Fig. 3. Depth profiles of ETS activity (ETSA) and carbon-specific ETS activity (C-specific ETSA):

- Station 1 ; $x--x=$ Station 2 $\boldsymbol{\Delta}-\boldsymbol{\Delta}=$ Station 3 .

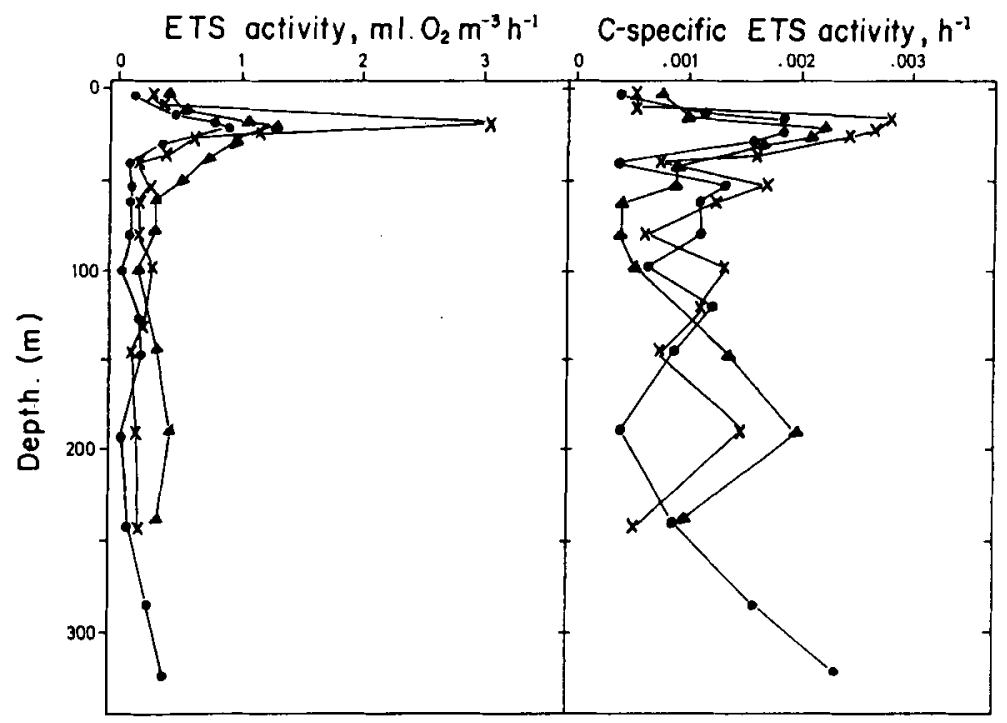

mum value of 105 , which indicates a moderately high proportion of phytoplankton in the total microplankton biomass.

ETS activity was converted to carbon units (mg C m ${ }^{-3} \mathrm{~h}^{-1}$ ), using a respiratory quotient RQ $=1$ (Packard 1979; Simpkins 1986; Shaffer 1987). The result was divided by POC concentration to find the (potential) carbon-specific respiratory rate, or carbon respiratory turnover, in (time) $)^{-1}$ units. The carbon respired ranged from 0.02 to $1.4 \mathrm{mg} \mathrm{C} \mathrm{m}^{-3} \mathrm{~h}^{-1}$ (mean $=0.22 \mathrm{mg}$ $\mathrm{C} \mathrm{m}^{-3} \mathrm{~h}^{-1}$ ). The carbon-specific rate (Fig. 3) ranged from 0.01 to $0.07 \mathrm{~h}^{-1}$ and was highest in the chlorophyll maximum, as were both biomass and absolute ETS, suggesting that at that depth the living biomass was both more abundant and more metabolically active.

\section{Depth-integrated values of biomass and activity}

Integral column values for the biomass and activity variables are summarised in Table 2 . Station 1 showed the lowest depth-integrated chlorophyll and ETS activity. POC and PON were similar at Stations 1 and 2 (26 and $23 \mathrm{~g} \mathrm{C} \mathrm{m}^{-2} ; 3$ and $2.6 \mathrm{~g} \mathrm{~N} \mathrm{~m}^{-2}$ ) and higher at Station 3: $43.4 \mathrm{~g} \mathrm{C}^{-}$ $\mathrm{m}^{-2}$ and $4 \mathrm{~g} \mathrm{~N} \mathrm{~m}^{-2}$. Chlorophyll $a$ was highest at Station 2: $61 \mathrm{mg} \mathrm{m}^{-2}$. ETS activity showed an increase in the Stations 1-2-3 sequence: $0.7,0.8$ and $1.1 \mathrm{~g} \mathrm{C} \mathrm{m}^{-2} \mathrm{~d}^{-1} . \mathrm{C} / \mathrm{N}$ ratio (atoms) of the integrated water column was 9 for Stations 1 and 2 and 11 for Station 3. Table 2 also shows the integral values for the 0-60 $\mathrm{m}$ water column, and the percentage of the total column contained in it. The distributions of biomass and activity at Station 2 were different from Stations 1 and 3,

Table 2. Depth-integrated values of biochemical variables. In parentheses, percentage of the total column value contained in the upper $60 \mathrm{~m}$.

\begin{tabular}{llllllrrr}
\hline $\begin{array}{l}\text { STA } \\
\text { no. }\end{array}$ & $\begin{array}{l}\text { Depth } \\
\text { range } \\
(\mathrm{m})\end{array}$ & $\begin{array}{l}\text { POC } \\
\left(\mathrm{g} \mathrm{m}^{-2}\right)\end{array}$ & $\begin{array}{l}\text { Chl a } \\
\left(\mathrm{mg} \mathrm{m}^{-2}\right)\end{array}$ & $\begin{array}{l}\text { ETSA } \\
\left(\mathrm{gC} \mathrm{m^{-2 }}\right. \\
\left.\mathrm{d}^{-1}\right)\end{array}$ & $\begin{array}{l}\text { C/N } \\
(\mathrm{at} / \mathrm{at})\end{array}$ & $\begin{array}{l}\text { C/Chl } \\
(\mathrm{w} / \mathrm{w})\end{array}$ & $\begin{array}{l}\text { ETS/Chl } \\
(\mathrm{gCgCh})^{-1} \\
\left.\mathrm{~d}^{-1}\right)\end{array}$ & $\begin{array}{l}\text { C-sp } \\
\text { ETS } \\
\left(\mathrm{d}^{-1}\right)\end{array}$ \\
\hline 1 & $0-60$ & $9.3(35 \%)$ & $5.5(52 \%)$ & $0.27(39 \%)$ & 8.2 & 206 & 49.0 & 0.03 \\
& $0-340$ & 26.4 & 10.6 & 0.69 & 8.8 & 2480 & 62.8 & 0.03 \\
2 & $0-60$ & $9.8(42 \%)$ & $54.5(90 \%)$ & $0.51(62 \%)$ & 7.6 & 180 & 9.4 & 0.05 \\
& $0-250$ & 23.3 & 60.8 & 0.82 & 8.8 & 383 & 14.0 & 0.04 \\
3 & $0-60$ & $17.3(40 \%)$ & $20.6(79 \%)$ & $0.49(44 \%)$ & 13.6 & 840 & 23.8 & 0.03 \\
& $0-255$ & 43.4 & 4.0 & 1.10 & 10.9 & 1685 & 42.7 & 0.03 \\
\hline
\end{tabular}


which exhibited strongly stratified water masses, and where $45 \%$ of POC. $73 \%$ of PON. $89 \%$ of chlorophyll and $62 \%$ of ETS activity took place above $60 \mathrm{~m}$.

Ratios between depth-integrated variables (Table 2) were calculated for the 60 upper $\mathrm{m}$ and the total column. The euphotic zone of Station 2 had the lowest $\mathrm{C} / \mathrm{N}$ ratio ( $7.6 \mathrm{at} / \mathrm{at})$, chlorophyllspecific POC $(180 \mathrm{~g} / \mathrm{g})$, PON $(43 \mathrm{~g} / \mathrm{g})$ and ETS activity $\left(9.4 \mathrm{~g} \mathrm{Cg} \mathrm{Chla}^{-1} \mathrm{~d}^{-1}\right)$ and the highest carbon-specific ETS activity $\left(5.2 \% \mathrm{~d}^{-1}\right)$, indicating that this water mass was the richest in phytoplankton and protein, and the most metabolically active.

\section{Discussion}

The in vitro ETS activity increased with temperature in the assayed interval $\left(0-12^{\circ} \mathrm{C}\right)$, showing a similar effect to that reported for other enzyme systems in cold-water organisms. Activation energy $\left(E_{a}\right)$ was $11.5 \mathrm{Kcal}_{\text {mole }}{ }^{-1}$, similar to the $E_{a}=12$ reported by Neori \& Holm-Hansen (1982) for photosynthesis of Antarctic phytoplankton at near-zero temperatures, and lower than the mean value $\left(E_{a}=16 \mathrm{Kcal} \mathrm{mole}^{-1}\right)$ found by Packard et al. (1975) for ETS activity in microplankton from several latitudes. However, temperatures in their study ranged between 9 and $28^{\circ} \mathrm{C}$ and did not include polar zones. $\mathrm{E}_{\mathrm{a}}$ in the present study falls in lower part of their range. This suggests that $E_{a}$ in cold-water microplankton is at the lower end of responses to naturally occurring temperatures, as postulated for photosynthesis and growth of polar phytoplankton (Neori \& Holm-Hansen 1982; Li et al. 1984; Harrison \& Platt 1986; Tilzer et al. 1986). However, bacterial growth in the Antarctic ocean was double of that predicted and had lower $Q_{10}$ than phytoplankton (1.4 versus 2$)$ for the $-1-$ $20^{\circ} \mathrm{C}$ temperature interval (Neori \& Holm-Hansen 1982). In this study. $Q_{111}=1.6\left(0-12^{\circ} \mathrm{C}\right)$ possibly reflects a variety of responses in the populations that compound the microplankton.

The ETS activity measured is a potential respiration rate, and can be converted to actual oxygen consumption ( $R$ ) by applying a factor derived from simultaneous $R$ and ETS activity measurements done on mixed plankton populations. Some calibrations (Packard \& Williams 1981: Williams 1984; Packard 1985a; Vosjan \& Nieuwland 1987) yield values of about 3 for the ETS/ $R$ ratio. However, these studies have been made on temperate microplankton from eutrophic surface waters. Although ETS activity and respiration are usually well correlated in a given area or plankton community (Packard \& Williams 1981), R/ETS ratio can vary with different plankton contributions or seasons (see Hobbie et al. 1972). R/ETS ratios increase with increased bacterial contribution to overall respiration since bacteria are usually more metabolically active than other organisms (Williams 1984; Azam \& Fuhrman 1984; Harrison 1986). Also, organisms in cold environments seem to use a larger proportion of their ETS for actual respiration (Jansky 1963). Additional problems relate to the long incubations needed to determine oxygen consumption with the micro-Winkler technique (Williams \& Jenkinson 1983); this could promote bacterial growth inside the incubation bottles, causing an apparent increase in respiration. These are reasons why ETS activity results have been directly reported here without conversion to oxygen consumption.

The ETS activities found in this study for the 100 upper $\mathrm{m}$ range between 0.5 to $100 \mathrm{mg} \mathrm{O}_{2} \mathrm{~m}^{-3}$ $\mathrm{d}^{-1}$ (mean value $13 \mathrm{mg} \mathrm{O}_{2} \mathrm{~m}^{-3} \mathrm{~d}^{-1}$ ), which is in the range found for oligotrophic oceanic regions (Williams 1984). Integrated daily rates for the upper $100 \mathrm{~m}$ were $1.7 \mathrm{~g} \mathrm{O}_{2} \mathrm{~m}^{-2} \mathrm{~d}^{-1}$ and $2.7 \mathrm{~g} \mathrm{O}_{2}$ $\mathrm{m}^{-2} \mathrm{~d}^{-1}$ for the whole water column. Williams (1984) quoted respiration rates in Antarctic microplankton $(0-100 \mathrm{~m})$ ranging from 0 to $16 \mathrm{mg} \mathrm{O}_{2}$ $\mathrm{m}^{-3} \mathrm{~d}^{-1}$, but FTS activity in the Weddell Sea (Martinez \& Estrada 1991) was higher: 0.2 to $53 \mathrm{mg} \mathrm{O} \mathrm{O}_{2} \mathrm{~m}^{-3} \mathrm{~d}^{-1}$. These values would range between one and three-fold those quoted by Williams, when applying an ETS/R ratio of 1 to 3. Vosjan \& Olańczuk-Neyman (1991) reported ETS activity of 2-200 $\mathrm{mg} \mathrm{O}_{2} \mathrm{~m}^{-3} \mathrm{~h}^{-1}$ in Admiralty Bay, Antarctica. Harrison (1986) found in the High Canadian Arctic $(0-100 \mathrm{~m})$ a mean value of $60 \mathrm{mg} \mathrm{O} \mathrm{m}^{-3} \mathrm{~d}^{-1}$ and integrated values $(100 \mathrm{~m})$ of $4-9 \mathrm{~g} \mathrm{O}_{2} \mathrm{~m}^{-2} \mathrm{~d}^{-1}$. ETS activity in this study was higher than in the Weddell Sea and lower than respiration in the Canadian Arctic.

Harrison's (1986) results were five-fold higher than in the present study, the main reason probably being the higher living biomass in the Canadian Arctic samples. Chlorophyll $a$ in the surface $(0-40 \mathrm{~m})$ waters of the Canadian Arctic ranged from 0.74 to $8 \mathrm{mg} \mathrm{m}^{-3}$, whereas at the Barents Sea stations they ranged from 0.05 to $3.3 \mathrm{mg} \mathrm{m}^{3}$. Respiration/Chl ratio in the Canadian Arctic (calculated from data from Harrison 1986) 
was $1.7 \mathrm{mg} \mathrm{O}_{2} \mathrm{mg} \mathrm{Chl}^{-1} \mathrm{~h}^{-1}$, and ETS/Chl in this study was similar, $1.9 \mathrm{mg} \mathrm{O}_{2} \mathrm{mg} \mathrm{Chl}^{-1} \mathrm{~h}^{-1}$. However, assuming that respiration is lower than ETS activity, the calculated ratio sets an upper limit for the $\mathrm{R} / \mathrm{Chl} a$ ratio in the Barents Sea.

ETS/Chl ratios reflect the relative contribution of autothrophs to total microplankton respiration. In phytoplankton-dominated zones, such as upwelling systems, ocean fronts or chlorophyll maximum layers, the ratio is low, and increases away from these zones. The ratio was $0.7 \mathrm{mg} \mathrm{O}$ mg $\mathrm{Chl}^{-1} \mathrm{~h}^{-1}$ at the chlorophyll maximum at Station 2, and increased to $2 \mathrm{mg} \mathrm{O}_{2} \mathrm{mg} \mathrm{Chl}^{-1} \mathrm{~h}^{-1}$ at the bottom of the euphotic zone at the same station. The range of this ratio was similar in the Weddell Sea during spring (Martinez 1989; Martinez \& Estrada 1991). In the Western Mediterranean Sea the ETS/Chl ratio ranged from $0.3 \mathrm{mg} \mathrm{O}_{2} \mathrm{mg} \mathrm{Chl}^{-1} \mathrm{~h}^{-1}$ (chlorophyll maximum and Almeria-Oran Front) and $5 \mathrm{mg} \mathrm{O}_{2} \mathrm{mg} \mathrm{Chl}^{-1}$ $\mathrm{h}^{-1}$ (oligotrophic central basin) (Martinez et al. 1990; Martinez unpubl. data).

The ETS activity, converted to carbon and day units, had a mean value of $5 \mathrm{mg} \mathrm{C} \mathrm{m}^{-3} \mathrm{~d}^{-1}$, with a range of $0.6-33.6 \mathrm{mg} \mathrm{C} \mathrm{m}^{-3} \mathrm{~d}^{-1}$. The carbonspecific rate, or (potential) respiratory carbon turnover, was $0.01-0.07 \mathrm{~d}^{-1}$ with a mean value of $0.03 \mathrm{~d}^{-1}$, and the integral column value ranged between 0.03 and $0.04 \mathrm{~d}^{-1}$. This means that 3 to $4 \%$ of the POC present is potentially consumed each day by respiration. This rate is in the same range as the rate observed in sediment trap material in the same region during the same cruise, between 40 and $300 \mathrm{~m}$ depth (Wassmann et al. 1991). $\mathrm{C} / \mathrm{N}$ ratios were similar: 11 in sedimenting versus 12 in suspended matter, indicating similar organic matter. This is in agreement with the characteristics of recycled production in summer in the region (Wassmann 1989; Wassmann et al. 1991).

Respiratory turnover rate of carbon in Barents Sea microplankton in summer was a fifth of the rates found in the Weddell Sea in spring: 0.02 to $0.05 \mathrm{~d}^{-1}$ with a mean of $0.17 \mathrm{~d}^{-1}$ (Martinez \& Estrada 1991), in spite of lower temperatures $\left(-1.7\right.$ to $\left.2^{\circ} \mathrm{C}\right)$. The reasons probably are the high living/dead organic matter ratio and high bacterial contribution in the Weddell Sea (Boldrin pers. comm.; Delille 1989), with $\mathrm{C} / \mathrm{N}$ ratios of 6.5 , close to $\mathrm{C} / \mathrm{N}=5.7$ reported for marine bacteria (Mann 1982). Vosjan \& Nieuwland (1987) found rates of $0.12 \mathrm{~d}^{-1}$ in Antarctic waters, and $0.3 \mathrm{~d}^{-1}$ in the North Atlantic during the spring bloom, and much higher values, averaging $0.9 \mathrm{~d}^{-1}$, in tropical waters at temperatures between 10 and $27^{\circ} \mathrm{C}$. High detrital/living ratios together with low temperatures account for the low carbon-specific enzyme activity found in the Barents Sea during summer.

Respiratory ETS activity of microplankton can be compared with existing data on primary production by phytoplankton in the Barents Sea by Rey et al. 1987. Their estimation of annual production was $69 \mathrm{~g} \mathrm{C} \mathrm{m}^{-2}$, taking place only during six months. We can assume that the ETS activities measured in this study are maintained during the same six months (a low estimation), and that respiration in the colder months is negligible. On basis of data from the more pelagic Stations 1 and 2 , the carbon potentially respired would average $140 \mathrm{~g} \mathrm{C} \mathrm{m}^{-2}$ for the six-month period. Using the $\mathrm{R} / \mathrm{ETS}=0.3$ ratio, this would correspond to $47 \mathrm{~g}$ $\mathrm{C} \mathrm{m}^{-2}$. Assuming that the numbers given by Rey et al. estimate net production of the microplankton community, then gross production, by adding microplankton respiration, would be between 116 (taking $\mathrm{R}=0.3$ ETS) and $209 \mathrm{~g} \mathrm{C}$ $\mathrm{m}^{-2}$ (taking $\left.\mathrm{R}=\mathrm{ETS}\right)$. This means a respiration of between $40 \%$ and $70 \%$ of gross primary production. Although this is a rough estimate, it provides an approach to estimate the range and order of magnitude of the production-respiration relationship in microplankton in the Barents Sea.

These results show that most of the respiratory activity of microplankton in the Barents Sea occurred in the upper layers $(<60 \mathrm{~m})$ and was correlated with phytoplankton biomass. Ranges of respiratory ETS activity, as well as columnintegrated values, were higher than those reported from the Antarctic (Williams 1984; Martinez \& Estrada 1991) and lower than respiration in other Arctic regions (Harrison 1986). It has been postulated that Arctic microplankton respiration may be substantially higher than that in the Antarctic. The results of this study do not support this hypothesis. My results rather provide evidence of the similarity of function between microplankton communities of Arctic and temperate oceanic areas.

Acknowledgements. - I am indebted to E. Sakshaug for the opportunity to participate in a Pro Mare cruise. H. R. Skjoldal, as the cruise leader, provided logistic support and cooperation, and allowed me to use the chlorophyll and nutrient data measured on board. The help provided by the staff at the Institute of Marine Research in Bergen is appreciated. Thanks are extended to the Department of Microbiology, University of Bergen, for allowing me to use their $\mathrm{CHN}$-analyzer. Comments 
and suggestions of E Sakshatig. T. T. Packard and wo anonymous reviewers are appreciated. Financial support was provided by the Pro Marc programme (Norway) and Grant PAO-86-(k)11 from the Spanish CICYT

\section{References}

Azam. F. \& Fuhrman, J. A [984: Measurement of bacterioplankton growth in the sea and its regulation by environmental conditions. Pp. 174-196 in Hobbic. J. E \& Williams. P. J. le B: Heterotrophic activity in the sea Plenum. N.Y

Chabot, B. F. 1979: Metabolic and enzymatic adaptations to low temperature. Pp. 283-301 in Underwood. L. S. et al. (eds.): Comparaive mechanisms of cold adaptation. Academic Press. USA

Delille. D.. Brandini. F. Kivi. K.. Kuosa, H. . Norrman. B. 1989: Microbial communitics. Ber. 2. Polarfors. 62. 113-116.

Harrison. W. P. 1986: Respiration and its size-dependence in microplankton populations from surface waters of the Canadian Arctic. Polar Biol. 6. 145-152.

Harrison. W. G. \& Platt. T 1986. Photosynthesis-irradiance rclationships in polar and temperate phytoplankton populations. Polar Biol. 5, 153-164.

Hobbic. J. E. Holm-Hansen. O., Packard, T. T. Pomeroy. L. R. Shcldon. R. W.. Thomas、G. P. \& Wiebe. W. J. 1972: A study of the distribution and activity of microorganisms in ocean water. Limnol. Oceanogr. 17. 544-555.

Hochachka. P. W. \& Somero, G. N. 1971: Biochemical adaptation to the environment. Pp. $94-165$ in Hoar. W. S. \& Randall. D. J. (eds.): Fish Phisiologi. Vol. 6. Academic Press.

Hochachka. P. W. \& Somero, G. N. 1973: Strategies of Biochemical Adaptation. Saunders. Philadelphia. $358 \mathrm{pp}$.

Jansky. L. 1963: Body organ cytochrome oxidase activity in cold-and warm-acclimated rats. Can. J. Biochem. Physiol. 41. $1847-1854$

Kenner, R. A. \& Ahmed, S. J 1975: Measurement of electron transport activities in marinc phytoplankton. Mar. Biol. 33. 119-128.

Li. W. K. W. Smith. J. C. \& Platt. T. 1984: Temperature response of photosynthetic capacity and carboxylase activity in Arctic marine phytoplankton. Mar. Ecol. Prog. Ser. 17. 237-243.

Mann, K. H. 1982: Ecology of coastal waters. A systems approach. Blackwcll. $322 \mathrm{pp}$

Martinez, R. 1989: The activity of the respiratory electron transport system in microplankton. Ber. Z. Polarfors. 62 . $138-141$

Martinez, R. \& Estrada. M. 1991: Respiratory ETS activity of microplankton in the Weddell Sea during spring: influence of the ice coverage. Polar Biol. In press.

Martinez. R., Arnone. R. A. \& Velasquez. Z. 1990: Chlorophyll $a$ and respiratory activity in microplankton from surface waters of the Western Mediterrancan Sea. J. Geophys. Res. g) $C ? 2,1615-1622$

Veori. A. \& Holm-Hansen. O. 1982: Effect of temperature on rate of photosynthesis in antarctic phytoplankton. Polar Biol. 1. 32-38.

Packard. T. T. 1971: The measurement of electron transport activity in marine phytoplankton. J. Mar. Res. 29. 235-244.

Packard. T. T. 1979: Respiration and respiratory electron transport activits in plankton from the Northwest African upwell. ing area, J. Mar. Res. 37. 711-74?.
Packard. T. T. 1985a: Measurement of electron transport activity of microplankton. Ads. Aquat. Microbiol. 3, 207261

Packard. T. T. 1985b: Oxygen consumption in the occan: measuring and mapping with enzyme analysis. Pp. 177-209 in Zirino. A. (ed.): Mapping Strategies in Chemical Ocean egrapiry. American Chemical Socicty. Washington. D.C.

Packard. T. T. \& Williams. P. J. k B. 1981: Rates of respiratory oxvgen consumption and electron transport in surface seawater from the Northwest Atlantic. Oceanol. Acta 4, 351$35 \%$.

Packard. T. T. Devol. A. H. \& King. F. D. 1975: The effect of temperature on the respiratory electron transport system in marine plankion. Deep-Sea Res. 22. 237-249.

Rey. F. \& Loeng. H. 1985: The influence of ice and hydrographic conditions on the development of phytoplankton in the Barents Sea. Pp. $49-63$ in Gray, J. \& Christiansen. M. E. (eds.): Marine biology of polar regions and the effects of stress on marine organisms. J. Wilcy and Sons.

Rey, F., Skjoldal. H. R. \& Slagstad, D. 1987: Primary production in relation to climatic changes in the Barents Sea. Pp. 29-46 in Loeng. H. (ed.): The effect of oceanographic conditions on distribution and population dynamics of commercial fish stocks in the Barents Sea. Proc. Sovict-Norwegian Symp. Murmansk. 26-28 May 1986.

Shaffer. G. 1987: Redficld ratios, primary production and organic carbon burial in the Baltic Sea. Deep-Sea Res. 34, $769-784$.

Simpkins. I. 1986: General principles of biochemical investigations. Pp. 1-42 in Wilson, K. \& Goulding. H. (eds.): Principles and Techniques of Practical Biochemistry. Arnold Press. London

Somero. G. 1969: Pyruvate kinase variants of the Alaskan king crab. Biochem. J. 114, 237-241.

Tilzer, M. M., Elbrächter. M. Gieskes, W. W. \& Beese. B. 1986: Light-temperature interactions in the control of photosynthesis in Antarctic phytoplankton. Polar. Biol. 5. $105-111$

Vosjan. J. H. \& Nieuwland. G. 1987: Microbial biomass and respiratory activity in the surface waters of the East Banda Sea and Northwest Arafura Sea at the time of southwest monsoon. Limnol. Oceanogr. 32, 767-775.

Vosjan. J. H. \& Olaniczuk-Neyman, K. M. 1991: Influence of temperature on respiratory ETS activity of micro-organisms from Admiralty Bay. Antarctica. Neth. J. Sea Res. 28. 221225

Wassmann. P. 1989: Sedimentation of organic matter and silicate from the cuphotic zone of the Barents Sea. Rapp. P-v Réun. Cons. Int. Explor. Mer 188, 108-114.

Wassmann. P.. Martinez. R. \& Vernet, M. 1991: Respiration and biochemical composition of sedimenting organic matter during summer in the Barents Sea. Cont. Shelf Res. In press.

Williams. P. J. le B. 1981: Microbial contribution to overall marine plankton metabolism: dircet measurements of respiration. Oceanol. Acra 4. 359-364.

Williams. P. J. le B. 1984: A review of measurements of respiration rates. Pp. 357-390 in Hobbie, J. E. \& Williams. P. J. le B. (eds.): Heterotrophic activity in the sea. NATO Conference Series. IV. 15. Plenum Press. New York.

Williams. P. J. le B. \& Jenkinson, N. W. 1983: A transportable microproccssor-controlled precise Winkler titration suitable for ficld station and shipboard use. Limnol. Oceanogr. 27. $576-584$ 